\title{
The urban public and forest land-use planning: Tapping into the majority
}

\author{
by Scott Kidd ${ }^{1}$ and A. John Sinclair²
}

\begin{abstract}
Canadians desire involvement in forest management at normative or early planning phases. One way of accomplishing this is through meaningful public involvement in land-use planning efforts. The Provinces of Ontario and Manitoba have, respectively, completed or are completing the development of land use plans for large areas of forested landscapes. Both governments identified public participation as being an integral part of these processes. This paper examines how well these processes promoted participation by the general public, the vast majority of which resides in urban areas located outside the respective planning regions. It is determined that in both cases this was poorly done. Reasons are given for why and how increased participation by the urban public should be pursued.
\end{abstract}

Key words: public involvement, land-use planning, forest management, urban centres, Lands for Life, East Side Planning Initiative, Canada

\section{RÉSUMÉ}

Les Canadiens et les Canadiennes souhaitent être impliqués dans l'application ou au cours des phases préliminaires de planification de l'aménagement forestier. Une façon de réaliser ce souhait réside dans l'implication significative du public dans les projets de planification de l'utilisation du territoire forestier. Les Provinces de l'Ontario et du Manitoba ont respectivement complété ou en voie de compléter l'élaboration de plans de développement de l'utilisation du territoire forestier pour de grands segments du domaine forestier. Les deux gouvernements ont retenu la participation du public en tant qu'élément intégral de ces processus. Cet article étudie si ces processus ont favorisé adéquatement la participation du grand public, qui en grande majorité réside dans des zones urbaines localisées à l'extérieur des régions sous planification. On reconnait que dans les deux cas que cela s'est fait d'une manière inappropriée. Les raisons permettant d'expliquer et de démontrer la nécessité d'accroître la participation du public urbain sont présentées.

Mots clés : participation du public, planification de l'utilisation du territoire, aménagement forestier, centres urbains, Lands for Life, East Side Planning Initiative, Canada

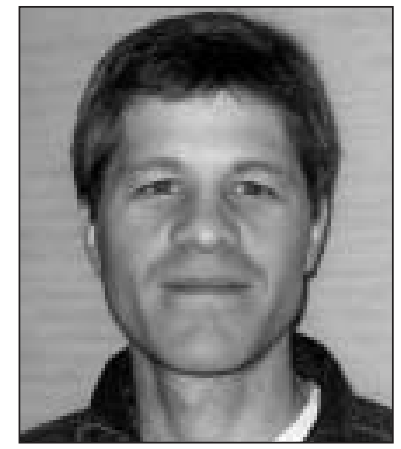

Scott Kidd

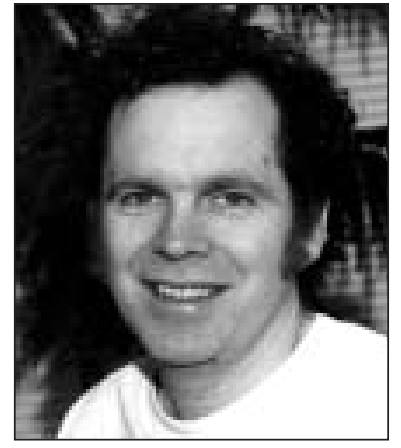

A. John Sinclair

\section{Introduction}

A World Resources Institute report (Bryant et al. 1997) notes that only $22 \%$ of the Earth's original forests remain as "frontier forests," which it defines as being forests that are large, ecologically intact and relatively undisturbed. Canada's tracts of boreal forest that have not been logged represent a significant portion of these remaining large forest ecosystems

(Bryant et al. 1997, UNEP 2001, Sanderson et al. 2002). The increasing scarcity and ecological significance of large undisturbed forests makes Canada's boreal forests that much more important globally. Accordingly, decisions to use or alter Canada's remaining boreal forests must be made carefully so that the ecological health of these forests is maintained (Parliament of Canada 1999). The same can be said for all of Canada's forest ecosystems, whether they be "frontier" or not.

Decision-making about the use of Canada's forests has evolved from a process that was largely bilateral and closed to one that is increasingly transactive and inclusive (Grant 1990; Higgelke and Duinker 1993; Ross 1995; Howlett and Rayner 1995, 1997; Blouin 1998). Beginning in the 1970s, the public sought a voice in forest decision-making (Howlett and Rayner 1995, 1997; Blouin 1998; Drushka 2003). It has continued to do so because, as Robinson et al. (2001) note, "Canada's provincial bureaucratically driven forest policy processes have been ineffective in producing information that leads to forest management and planning that best reflect Canadian societal values."

The policies directing forest management and planning have typically not reflected Canadian societal values because

\footnotetext{
${ }^{1}$ Research Assistant, 101 Cedar Grove Drive, Quispamsis, New Brunswick E2E 4P1.

${ }^{2}$ Professor, Natural Resources Institute, University of Manitoba, Winnipeg, Manitoba R3T 2N2.
} 
of the divergence in views of provincial government forestry departments and forest product companies on the one hand, and the public on the other, about what Canada's forests should be managed for. The former have traditionally managed forests as a resource for the production of timber and fibre (Howlett and Rayner 1995, Blouin 1998). In contrast, 93\% of Canadians agree that forests should be managed for a wide variety of benefits and uses, notably protecting ecological services, rather than for timber production alone (Robinson et al. 2001). These conflicting values have been one of the main drivers of more participatory forest management decision-making.

Canada's federal and provincial governments have recognized the desire of Canadians to participate in forest-use decisions (CFS 1997). The Canada Forest Accord, 1992-1997, signed by Canadian federal and provincial governments, nongovernment organizations (NGOs), and members of Canada's forestry industries, states, "Canadians are entitled to participate in determining how their forests are used and the purposes for which they are managed" (CCFM 1992). The fact that $94 \%$ of Canada's forests are publicly owned underscores the CCFM recognition that the "public has the right to a more direct say in setting objectives, developing policies and planning forest management." Emerging models of sustainable forest management (SFM) also require systematic consideration of the social, economic and environmental implications of forest use, the inclusion of diverse public values in decision-making, and meaningful public participation in forest management (CCFM 1999, Shindler et al. 2003).

Recognizing the need to involve people more meaningfully in forest management decision-making and at the same time make responsible decisions about forest use, several Canadian provinces have, or are in the process of developing, land use plans for large areas of forested landscapes. In Canada, land-use planning is seen as a component of ecosystem-based forest management (NFSC 2003). Typically, the stated aim of the processes that produce these plans is to identify zones and management objectives across the chosen forested landscape that will provide for the preservation of ecological health while at the same time allowing continued, increased or new human use of the land and its resources. Furthermore, provincial governments usually identify public participation as a cornerstone of their wide-area planning processes. The stated reasons for this are both to seek the public's input on how forests should be managed and also to tap into their values so that the plans implemented are reflective of what people want.

To promote this public involvement, various techniques have and are being used from surveys to open houses within a round-table planning approach. However, despite these efforts, Robinson et al. (2001) note, "[I]nput [into Canadian forest management] is broadly solicited but usually received from the narrow foci of unrepresentative and often polarized extremes. Given that traditional participation processes are also more easily accessed and influenced by organized interests, a significant challenge is to ensure broad, balanced participation by the general public" (emphasis added). So, despite this new trend in public involvement, specific ways of meaningfully involving the general public in forest management planning are still being tested. As will be discussed further below, the vast majority of Canadians reside in urban areas, making the "general public" largely an urban public. As forest-management planning processes apply to large publicly owned forest regions and therefore have implications for the urban majority of "owners," important lessons could be learned from considering how this sector of the population has been involved in these planning efforts.

The purpose of this article, therefore, is to consider how the urban public's voice was included in two large-area landuse planning processes for significant portions of Canada's boreal forest: Manitoba's East Side Planning Initiative (ESPI), and Ontario's Lands for Life process (OLL). (OLL also involved planning for the Great Lakes-St. Lawrence forest type located along the shores of Lake Superior and Lake Huron (Georgian Bay)). The approach taken was interactive and adaptive and involved document review, direct participation in the ESPI case and interviews with key participants in the OLL case.

\section{Why focus on large urban centres?}

With regard to Canadian forest management planning, attention must be paid to large urban centres because they contain a disproportionate amount (79.4\%) of the Canadian general public (Statistics Canada 2004a), the "owners" of our public forests and voters of elected politicians. For example, the population of the Province of Manitoba in 2001, where the ESPI is being conducted, was 1.151 million people. The City of Winnipeg, which is Manitoba's largest city and is located in southern Manitoba, had a population of 690100 people in 2001, 60\% of the provincial population (Statistics Canada 2004b). The population of the Province of Ontario in 2001, where OLL was conducted, was 11.897 million people. The vast majority of its population lives in the heavily urbanized region of southern Ontario. For example, a region called the "Golden Horseshoe," which includes the City of Toronto and surrounding cities such as Hamilton, accounted for $59 \%$ of Ontario's population (Statistics Canada 2004c). This pattern of a heavily populated south repeats itself throughout Canada. As a result, the vast majority of Canada's urban centres are not located in the boreal forest, which covers 53\% of Canada's land mass and stretches through north-central Canada from east coast to west coast (Global Forest Watch Canada 2000).

In addition to the fairness of including the large majority of Canadians in management decisions regarding public forests, the residents of urban centres could also have a large impact upon the political fate of land-use plans for regions of Canada's boreal forest. In other words, a land-use planning process that fails effectively to promote participation by the urban public places the ultimate acceptance and implementation of the plan in jeopardy. For example, the ESPI planning region covers approximately 13\% of Manitoba's land mass (ESPI undated). However, because of its sparse population, it is represented in the Manitoba Legislature by only one of Manitoba's 57 electoral districts. Residents of the City of Winnipeg are represented by 31 of Manitoba's electoral districts. Bearing in mind the sociopolitical context under which resource-use decisions are made, Winnipeg voters, if motivated, could easily overwhelm the voting preferences of residents of the ESPI region.

Voters in Winnipeg take on even greater significance when viewed in the light of Manitoba's highly polarized election 
results since 1969. As Peterson (1972) notes, since that time, electoral districts in the more affluent, southern rural portion of Manitoba almost always vote for Manitoba's Progressive Conservative Party (PC). With the exception of one electoral district in one election, the poorer, northern portion of Manitoba has since 1969 elected members of Manitoba's New Democratic Party (NDP) (WFP 2003). This polarization is also evident in Winnipeg, with the electoral districts in the northern part of the city usually electing NDP members, while residents of the city's southern electoral districts usually elect PC party members. This makes a handful of electoral districts in central Winnipeg, known as "swing" ridings, crucial to determining which political party will form the government. A well-executed campaign by an interest group could put pressure upon an elected representative from a swing riding to support or oppose a proposed land-use plan for the ESPI planning region. Failure to do as the interest group wishes could result in the loss of that electoral district in the next election. A loss of several swing ridings would make it difficult for a political party in Manitoba to win enough ridings to form a majority government.

This strategy was used successfully, for example, in Ontario with regard to a different natural-resource issuethe cancellation of the spring bear hunt. In late 1997, several NGOs initiated a campaign calling for the Ontario Government to ban the annual spring bear hunt. This effort met with little success, with the Natural Resources Minister for Ontario stating in April 1998, "a ban is out of the question” (Toronto Star 1998a). In November 1998, these groups tried a different tactic. They ran a targeted campaign directed at eight ridings located in the heavily urbanized Golden Horseshoe of Ontario held by members of the then-in-power Progressive Conservative (PC) Party. The groups believed the PCs were vulnerable in these ridings in the next election. They flooded them with radio, bus-shelter and billboard advertising calling on the Ontario Government to end the spring bear hunt. They also distributed 15000 copies of a campaign video door-to-door (Toronto Star 1998b).

For the NGOs, the campaign was a success. The eight PC members were flooded with calls from constituents who wanted the hunt cancelled (Toronto Star 1999a). On January 15,1999 , less than ten months after saying the hunt would not be cancelled, the Ontario Government announced the bear hunt for that spring would be cancelled (Toronto Star 1999b). It remains so. It is clear from the above example that the Canadian urban public, if motivated, can have a strong influence on the outcome of seemingly rural natural-resource issues.

\section{Public Involvement in ESPI and OLL Manitoba's East Side Planning Initiative}

Bounded by the eastern shore of Lake Winnipeg and the Manitoba-Ontario border, the area of Manitoba's "East Side" forest that lies north of the Bloodvein River "contains one of the largest areas of continuous undeveloped boreal forest in North America" (Government of Manitoba, Department of Conservation 2002). As there are calls to open the area to logging, mining operations, hydro transmission-line corridors, and an extensive all-weather road system, how undeveloped this region of boreal forest will remain is in question. In keeping with an earlier commitment to large-area land-use plan- ning, on August 9, 2000, the Manitoba Government announced that it was "initiating the process of wide area planning for land and resource use on the east side of Lake Winnipeg" (Government of Manitoba 2000). The planning area of the East Side Planning Initiative (ESPI) covers a portion of the undeveloped East Side forest as well as an area of boreal forest south of the Bloodvein River that has a lengthy history of use for recreation and industrial development including logging.

The objective of the Manitoba Government's planning process is described as follows:

"To bring together local communities, First Nations, industry and environmental organizations to develop a vision for land and resource use in the area that respects both the value of the boreal forest and the needs of local communities. It is expected the east side process will result in a blueprint for the area that will address protected areas, traditional activities, transportation needs and economic development. It is also expected that the east side process may result in recommendations on further study or consultation that may be needed following the submission of the east side plan" (Government of Manitoba 2002).

Since the planning process is ongoing in that a land-use plan has not been released, the final outcome as measured against these ideals remains in question. However, a review of how participation by citizens of the City of Winnipeg has been promoted during the process to date is still revealing. To begin, the ESPI consultation was originally to be carried out in two phases. The first phase was described as "preliminary consultations." Phase Two was to culminate with the completion of a recommended land-use plan for the region, but instead resulted in a status report being presented to the Manitoba Government in November 2004 that contained a number of recommendations regarding further planning efforts. A third phase of the ESPI, which is now entitled Wabanong Nakaygum Okimawim (WNO) (meaning "East Side of the Lake Governance"), is now underway.

\section{Phase One of the ESPI}

As outlined on the calendar of events in Table 1, in November 2000 , notice of the beginning of Phase One was placed in the province's environmental assessment public registry along with a two-page newsletter. Following this, a three-member team of government staff held a series of fourteen meetings with East Side aboriginal and non-aboriginal communities, industry, and various environmental non-government organizations (ENGOs) and other interest groups. Notice of these meetings came by direct mail. Attendees of some meetings, and in particular the meeting with ENGOs, were residents of the City of Winnipeg. However, no meeting with the general public or an open house was held in Winnipeg. The meetings took place from January to April 2001.

On November 9, 2001, a government news release announced the availability of the draft ESPI Phase One Report for public review and comment. Titled a "What You Told Us" document, the report contained the three-member team's recommendations on the steps and timing of the process, boundaries for the planning area, establishment of various planning committees, and major planning issues, including treaty and Aboriginal rights, resource development, 
Table 1. Phase One timeline for Manitoba's East Side Planning Initiative.

\begin{tabular}{|c|c|c|c|}
\hline Date & Action & Public Notice & Comment \\
\hline August 9, 2000 & Announcement of ESPI to begin & News Release & $\begin{array}{l}\text { No other documentation, } \\
\text { i.e., newsletter, accompanied } \\
\text { the news release }\end{array}$ \\
\hline November 2000 & $\begin{array}{l}\text { ESPI Newsletter \#1 placed in Manitoba Government's } \\
\text { environmental assessment public registry }\end{array}$ & $\begin{array}{l}\text { Public registry } \\
\text { Government Web site }\end{array}$ & $\begin{array}{l}\text { No public notice of the } \\
\text { release of the newsletter }\end{array}$ \\
\hline January - April 2001 & Meetings with interest groups and aboriginal communities & None & By invitation only \\
\hline November 2001 & $\begin{array}{l}\text { Release of draft East Side Lake Winnipeg, } \\
\text { Phase I Report for comment }\end{array}$ & $\begin{array}{l}\text { News Release } \\
\text { Public registry } \\
\text { Government Web site }\end{array}$ & $\begin{array}{l}\text { 30-day comment period } \\
\text { (extended to } 60 \text { days) }\end{array}$ \\
\hline March 7, 2002 & Chairperson for ESPI Phase Two appointed & News Release & $\begin{array}{l}\text { Occurred prior to release of } \\
\text { final Phase I report incorpo- } \\
\text { rating public comments }\end{array}$ \\
\hline May 14,2002 & ESPI Phase Two Round Table meetings take place & News Release & $\begin{array}{l}\text { Final Phase I report still not } \\
\text { released }\end{array}$ \\
\hline October 2002 & Final ESPI Phase I Report released & $\begin{array}{l}\text { Public Registry } \\
\text { Government Website }\end{array}$ & $\begin{array}{l}\text { No public notice of the } \\
\text { release of the final report }\end{array}$ \\
\hline
\end{tabular}

and protected areas (Government of Manitoba 2001). Comments on the draft report were to be returned to the government within thirty days, although the comment period was later extended to nearly two months.

Phase One of ESPI concluded in October 2002 with the release to the public of the final Phase One Report. The final report contained details of the Phase Two planning process. Of note is that ESPI Phase Two activities began taking place six months before the public release of the Final Phase One Report.

\section{Phase Two of the ESPI}

Before the completion of Phase I, a government-appointed twenty-member round table began meeting in May 2002. The Round Table was tasked with conducting Phase Two of Manitoba's East Side Planning Initiative. The Round Table's mandate was to "...provide recommendations and direction to the Manitoba Government on the development of a Broad Area Land Use Plan for the East Side of Lake Winnipeg..." (Government of Manitoba (undated)). There were twenty individuals on the Round Table plus a chairperson. The members of the Round Table were to "represent the public interest and not their organizations" (Government of Manitoba 2002: Recommendation 29). One role of the Round Table was to conduct public consultations. Finally, the Round Table was to provide its recommendations on a landuse plan by June 2004, a two-year period.

An East Side First Nation Council and an East Side Advisory Committee were also established to assist the Round Table in the preparation of the recommended land-use plan. The East Side First Nation Council was comprised of representatives from each of the sixteen First Nation communities within the ESPI planning area. The Advisory Committee had fifty-seven members who represented a number of interests, including First Nation and Métis organizations, local governments, resource industries, social, recreational, and environmental non-government organizations, and tourism businesses. Organized stakeholder groups located in the City of Winnipeg were represented on the Advisory Council, occupying fifteen of fifty-seven member seats, most of whom participated on behalf of ENGOs like Resource Conservation Manitoba and the Manitoba Eco-Network. Members of these two committees were to "represent the First Nation community and organizations to which they are affiliated" (Government of Manitoba 2002: Recommendation 36). The initial role of these two committees was to provide direction to the Round Table on items such as the goals, objectives and values for the final land-use plan, issues and concerns to be addressed, and the conduct of public meetings. The First Nations Council held eight reported meetings starting in February 2003, while the Advisory Committee met four times, also starting in February 2003. All of the Advisory Committee's meetings took place in Winnipeg.

With regard to the issue of public participation, the focus of the ESPI Round Table was on the communities located in the planning area. The City of Winnipeg is not located in the ESPI planning area. Beginning in September 2003, members of the Round Table conducted over 80 public meetings in most of the First Nations, Métis, and Manitoba Northern Affairs communities located in the planning area. Comments and minutes from these meetings were compiled and provided substance for many of the recommendations contained in the Phase Two status report. In March 2004, five government ministers traveled to fourteen East Side First Nation's communities to meet with community members. The Round Table also met separately with Elders from these communities 
to hear their thoughts on possible industrial developments in the region and the planning process itself.

The first formal and advertised opportunity for the general public, including the citizens of Winnipeg, to participate in Phase Two of the ESPI did not take place until a series of three public open houses were held in May 2004, despite the June $1^{\text {st }}$ deadline for the process to end. Two of the open houses took place in smaller urban centres (Thompson and Lac du Bonnet), while the final open house was held in Winnipeg on May 26, 2004. Notice of the public meeting was placed in newspapers including the provincially distributed Winnipeg Free Press three weeks in advance of the open house in Winnipeg. The open house took place from 10:00 a.m. to 9:00 p.m. at a central location in the city. The open house consisted of a series of storyboards and maps that were to explain the process and findings to date. Government representatives and consultants were on hand to answer questions. After viewing the storyboards, attendees were invited to complete an exit questionnaire about what they thought components of the final East Side land-use plan, such as community development or the protection of the environment, should address. If attendees did not have time to complete the questionnaire, they were invited to mail or email their questionnaire or other comments in. The questionnaire and storyboards were not available on the government Web site on the date of the open house nor several weeks afterwards. None of the storyboards provided a description of the remainder of the consultation process for the general public, such as a timeline or how their comments would be addressed or incorporated into the land-use plan. Eighty-five people attended the open house held in Winnipeg (ESPI 2004: Appendix 8).

To conclude Phase Two, on November 16, 2004, the ESPI Round Table presented the above-mentioned status report to the Minister of Conservation. The report contains a significant number of recommendations regarding how the government can complete the development of a large-area land-use plan for the ESPI region. The report is available to the public on the government's Web site, but no plans have been released for its public review and comment. Other than the release of a December 13, 2004, press release and the Phase Two status report, little information on the status of the WNO is publicly available. ${ }^{3}$ Finally, the status report was presented to the government without it being reviewed by all members of the Advisory Committee and First Nations Council, nor being reviewed and endorsed by all members of the ESPI Round Table.

\section{Ontario's Lands for Life process}

In February 1997, the Government of Ontario announced that it would undertake a program to prepare a plan that would govern the future use of 39 million hectares of Ontario's Crown lands and resources. Over a period of years prior to 1997 , forestry companies had been granted tenure to, or the right to log much of, the planning region. The granting of these tenures caused conflict because some people felt they prevented the preservation of important areas in the planning region. This land-use planning process, which the Ontario Government entitled Lands for Life (OLL), was undertaken

\footnotetext{
${ }^{3}$ Information on Wabanong Nakaygum Okimawim can be accessed at http://www.gov.mb.ca/conservation/wno/.
}

to deal with the conflict between forest exploitation and preservation (Castrilli 2002).

The Lands for Life planning region covered the central and "near-north" parts of Ontario. Most of the land is publicly owned and it is Ontario's most heavily forested region. Southern Ontario, including the Golden Horseshoe, was excluded from Lands for Life because much of the land in this region is privately owned or no longer heavily forested, while northern Ontario was excluded because the Ontario government had not yet made important policy decisions regarding use and allocation of the region (Government of Ontario 2001). The Lands for Life planning region was further divided into three planning areas: Boreal West, Boreal East, and Great Lakes-St. Lawrence.

In June 1997, the government appointed a Round Table for each of the three respective planning areas that included fourteen members and one chair. Only residents of the planning area were permitted to sit on its respective Round Table, thereby excluding southern Ontarians. After consulting with the public, each Round Table was to prepare and recommend a draft regional land-use strategy for its planning area (Government of Ontario 1998). These reports were to have been submitted by April 1, 1998. In conducting their consultations and preparing their recommendations, the Round Tables were to focus on the following four Ontario Government objectives:

- Completing the Ontario's system of provincial parks and other protected areas.

- Recognizing the land-use planning needs of the resourcebased tourism industry.

- Providing the forest, mining, and other resource industries with greater land- and resource-use certainty.

- Enhancing angling, hunting, and other Crown-land recreation opportunities (Government of Ontario 2001).

After spending the summer of 1997 doing background work, the Round Tables each began their separate public-consultation programs on August 8, 1997 by placing "An Invitation to Participate in the development of the [Lands for Life] Land Use Strategy" in the Government of Ontario's Environmental Bill of Rights Registry (EBR Registry). Following this, the Round Tables entered into an issue-identification stage from September 1997 to February 1998. Each Round Table held open houses in communities in their planning areas such as Kenora in the Boreal West planning region, Timmins in the Boreal East planning region, and Sault Ste. Marie in the Great Lakes-St. Lawrence planning region, to gather opinion from the public on the key issues for each planning region. During this period, the Boreal West Round Table visited 14 communities, the Boreal East visited nine communities, and the Great Lakes-St. Lawrence Round Table visited six communities (Government of Ontario 2001). The purpose of these open houses was described as follows:

"For this stage of the process, there were no specific proposals to which the public could react, only the broad objectives for the process overall. The meetings offered the public a chance to learn a bit of background information on the natural resources and issues of the region, to chat in an "open house" format with the Round Table members, and to present briefs and oral presentations to the Round Tables." (Government of Ontario 2001). 
Citizens were made aware of the open houses through the EBR Registry, mailing lists, province-wide newspaper advertisements and the Ministry of Natural Resources (MNR) Web site (Government of Ontario 2001). The format for the open houses was to first provide the public with the opportunity to view background material on OLL, through approaches such as storyboards, and to talk to members of each Round Table. Later in the open house, a public meeting or forum was held, at which members of the public could make submissions to the respective Round Table. Describing the response to the initial public meetings and invitations to participate as "overwhelming," the Minister of Natural Resources extended the deadline for the Round Tables' reports to June 30, 1998.

It was initially envisioned that input into the planning processes of the Round Tables would only be received and accepted from those living in the planning region. In light of this, no public meetings were to take place in southern Ontario. After receiving complaints from residents of Southern Ontario and a recommendation from the Environmental Commissioner of Ontario that the Ontario Ministry of Natural Resources consult with "Ontarians from all parts of the province," (ECO 1997) this decision was revisited and open houses with public meetings for the issue identification stage were held in four southern Ontario cities; Kingston, London, Ottawa, and Toronto. However, it was not until October 16, 1997, that the government released a press release announcing the southern Ontario meetings, with the Toronto meeting taking place on October 22. Six hundred and two people attended the first round of open houses in southern Ontario (Government of Ontario 2001). The public meetings were held in central locations in the above cities.

In the winter and spring of 1998, the three Round Tables individually developed various planning options and scenarios. These scenarios and other background information were first presented to the public by way of the EBR Registry, with the Great Lakes-St. Lawrence Round Table doing so in February 1998, the Boreal East Round Table in March, and the Boreal West Round Table in June. During this period, the Round Tables held further open houses/public meetings in their respective planning regions to gather public input on the planning scenarios. As well, a second round of joint open houses/public meetings was held in southern Ontario (Kingston, London, Ottawa, and Toronto) in March and April of 1998. As the Boreal West Round Table had not prepared its planning options at this time, it simply presented "ideas" at these meetings (Government of Ontario 2001). After it developed its planning options, it conducted a third round of public meetings in June 1998, including four in southern Ontario. Notice of the open houses came through various media, mailing lists and Web sites. The public was asked to respond to the scenarios presented by the Round Tables by completing workbooks, of which 6820 were returned (Government of Ontario 2001).

After receiving another one-month extension, the three Round Tables presented their reports and recommendations to the Minister of Natural Resources on July 31, 1998. Given the disparate form and content of the three reports, the chairs of the Round Tables were tasked with preparing a set of consolidated recommendations. This was completed in October. A government news release (October 30) and EBR Registry posting announced the availability of the report and a 30-day deadline for comments. However, as the Environmental Commissioner of Ontario reported, many people had signed up on the Round Tables' mailing lists to receive a copy of the consolidated recommendations. For reasons not explained, the Ministry of Natural Resources did not mail out copies of the consolidated recommendations or send letters telling people the report was available (ECO 1998). These people had either to request a copy of the report, to read it on the Internet, or to consult it at a Ministry of Natural Resources OLL reading room. The government received over 14000 responses from the public regarding the consolidated recommendations. Despite this level of response, residents of southern Ontario continued to voice concerns that the process did not provide for meaningful participation by them, and that there was insufficient consultation regarding the Round Tables' consolidated recommendations (Government of Ontario 2001).

The overall public response to the consolidated report and its recommendations was largely negative with the primary complaint (9600 of 14000 responses) being that the recommendations did little to increase the amount of protected forest area in the planning region (Government of Ontario 2001). To address this and other issues, and to bring closure to the Lands for Life process, the Ontario Government arranged private negotiation sessions in the winter of 1998 between three environmental groups and several of the largest forest companies operating in the planning region. These negotiations resulted in the signing of the 1999 Ontario Forest Accord by the negotiating parties and the Ontario Government. The Accord detailed a list of commitments made by the three parties, including:

- $12 \%$ of the planning area to be protected from forestry and mining.

- No reduction in wood supply to industry.

- No increase in the cost of wood to mills.

- Financial compensation to the forest industry.

- A review of forest management planning guidelines (ECO 1999/2000).

Following the completion of these negotiations and the 1999 Forest Accord, the Ontario Government on March 29, 1999 released for public review a Proposed Land Use Strategy (PLUS) for the planning region. The Strategy captured many of the policy decisions made by the Ontario Government as a result of the commitments contained within the 1999 Forest Accord (ECO 1999/2000). Notice of the 31-day comment period for the Strategy was provided on the EBR Registry and MNR Web sites. The government received 8300 public responses regarding the Strategy (Government of Ontario 2001). In July 1999, the completed land-use strategy for the OLL region, which was much in keeping with the PLUS, entitled Ontario's Living Legacy, was released, bringing an end to the Lands for Life planning process.

By the end of Ontario's Lands for Life land-use planning process, 190 public meetings were attended by 15000 people. In addition, from the beginning to the end of the planning process, the Round Tables and MNR received over 40000 public responses by way of mail, faxes, emails, phone calls, workbooks, presentations, and petitions (Government of Ontario 2001). 


\section{The Urban Majorities Participation in Wide-Area Planning}

In response to a national survey, Robinson et al. (2001) reported that "seventy-four percent of respondents endorsed citizen participation in setting management goals for public forests, preferring a level of participation where the public acts as a full and equal partner" (emphasis added). The findings of this study show that despite the focus in both case studies being planning for large tracts of public land, the results of which would have implications for all citizens, public involvement events were centred on locally affected communities. In both cases, the citizens of large urban areas were only brought into the process in a late and cursory fashion.

The approach used to involve the locally affected public was largely intensive. Both the OLL and the ESPI used a Round Table approach to public involvement. The Round Tables themselves allowed their citizen participants to engage in face-to-face discussions with provisions for doing research and collecting information. They also had the resources to involve local communities in their deliberations and regularly held meetings in those communities. While the focus of this research was on the involvement of urbanites, and thus a thorough analysis of how local communities were involved was not carried out, it is clear that organizers attempted to use mechanisms that allowed for high levels of dialogue and provided the time for that dialogue to occur in these local communities.

However, after empowering local communities in this way, the resulting plans went into a proverbial black hole and, at least in the case of Ontario, a much less democratic approach (private negotiations) was used for making the final decision. Given the consultation effort that had been undertaken and the expectation it created for further public involvement, it was improper for both the proposed and subsequent final land-use strategy for the OLL planning region, and the major policy decisions they contained, to ultimately be the result of the private tripartite negotiations. As the Environmental Commissioner of Ontario noted, "[T]he government had already announced the major policy decisions contained in the proposed [PLUS] Strategy, which suggests that the public comment period was only a formality and that the public's comments would have little chance of changing the decision [final land use plan]" (ECO 1999/2000). Clearly, the public, local and urban, was not a "full and equal partner" in the final decisions that were taken about public forest lands through the OLL. The lack of an opportunity for the public to review and comment on the ESPI Phase Two status report suggests that a similar result may also occur in Manitoba. Certainly the present lack of information for the ongoing planning process is discouraging.

It is unfortunate that the organizers did not use a variety of methods to give interested citizens of large urban areas a voice in the two planning efforts. In the case of the ESPI, the open house held in the City of Winnipeg only attracted 85 of its 690000 citizens. While some might view this as a good turnout for an open house, it certainly did not work as the only tool for involving the citizens of Winnipeg. It might, however, have been a good on-ramp to more inclusive participation. It is surprising that more effort was not given to involving citizens of Winnipeg given their proximity to, familiarity with, and fairly intensive use of the southern por- tions of the ESPI planning area. In the case of OLL, organizers had inexplicably planned not to involve people from large urban centres. Their belated efforts at involvement resulted in extremely limited input. As discussed earlier, there were over 40000 submissions made by the public during Ontario's Lands for Life land-use planning process. Even if it is assumed that all of these submissions came from the citizens of Ontario's Golden Horseshoe (which they did not) and disregarding multiple submissions from individuals, only 0.56 percent of the citizens of the region participated in Lands for Life. As a recent case study on OLL notes, "residents of southern Ontario- the majority of Ontarians-felt left out of the process..." (NRTEE 2003).

In both processes, some provision was made to involve stakeholder groups located in large urban centres in an attempt to at least garner some of the views of the general public. These groups were, however, not representing the views of citizens of any given urban area but rather the views of their organization and its members. Other research (Parkins 2002, McGurk et al. 2006) indicates, however, that there is often a breakdown between groups and their representatives during long stakeholder consultations, so we cannot confirm whose views were being brought to the table. We do know that with the ESPI no provision was made to help these participants in reporting back to their groups.

Returning to Manitoba, another example of the lack of public involvement or knowledge regarding Phase One of the ESPI is evidenced by the fact that only fifty comments on the draft Phase One Report were received from people not actively engaged in the planning process, i.e., the general public. In addition, these fifty comments resulted from a request of an ENGO to its members to provide comments on the Phase One report. The government later classified these fifty comments as one petition. The importance of community groups to the generation of public response was also seen in OLL. Of the 8300 responses to the Proposed Land Use Strategy received by the government, $89 \%$ were in the form of postcards and other form letters (Government of Ontario 2001). Both of these examples suggest that without the work of community groups, the already diminutive number of public participants in the respective planning process would have been smaller.

Clearly, the number of urban participants in the two landuse planning processes was small, and the process used to involve them inadequate to give urban citizens an effective voice in the planning. We suggest there are at least six reasons why there were so few urban participants.

1. The urban public was brought in late to these processes In both cases, significant planning had been completed before the urban public was invited to participate. As a result, some potential participants would have recognized the opportunity to participate as being nothing more than token effort and a waste of their time.

2. Notice of open houses was provided late - An essential component of good public involvement is early and effective notice. In both cases, notice was late and provided primarily through government postings and local papers.

3. Poor preparatory material - Information is key to effective participation. For example, in the case of ESPI, citizens not familiar with the process would have had to review volumes of material located in public registries to get up to 
speed. With regard to OLL, the Environmental Commissioner of Ontario wrote, "In general, although a great deal of information was made available... some important documents were difficult to obtain, and there were inconsistencies in the information provided by the different Round Tables" (ECO 1998).

4. Little chance for interactive discussion - Interactive discussion, or two-way dialogue, is essential to meaningful participation. Such dialogue allows people to articulate and discuss and refine their views and also identify other participants with similar views. In the case of ESPI, the open house was not set up in a way that provided for an open public discussion. Rather, people walked though a series of story boards and could ask questions of "officials." The OLL planning process did provide opportunities for this interactive discussion to occur.

5. Reliance upon too few public involvement tools - Many tools are well articulated in the literature and could be used in different situations (see for example: Diduck and Sinclair 1997, Sterne and Zagon 1997, Buchy and Hoverman 2000, Connor 2001, CSA 2002). In these cases, the tried and tested tools of open houses, public forums, exit questionnaires, and workbooks were relied on extensively to involve the urban population. In the context of meaningful participation, that includes dialogue and deliberation, these tools are best used as an on-ramp to the more deliberative/collaborative involvement techniques.

6. Lack of resources - Often people need assistance to participate in planning efforts. While resources were given to the Round Tables, a disproportionate amount of time and resources was dedicated to involving the local public versus the urban public. Many of the above-noted shortcomings revealed through the data correspond with the reasons for poor public participation in forest management in Canada (see for example: Duinker 1998, Robinson et al. 2001, Parkins 2002, Chambers and Beckley 2003, Steadman and Parkins 2003, Wellstead et al. 2003).

For any particular public-involvement program, it can be expected that a large majority of the potentially affected publics will not participate in the program (Praxis 1988, Creighton 1995, Roberts 1995, Petts 1999). So the question that remains is whether more urban citizens would have participated had the six deficiencies noted above been corrected. Given that these deficiencies are common and thus all identified in the literature as important considerations for facilitating good public involvement, we feel that attention to each would have resulted in much better representation of the urban population. Of course, other important shortcomings of public involvement processes also have to be considered, such as lack of impact on ultimate decisions, and lack of attention to the needs of the people being consulted with. For example, Diduck and Sinclair (2002) found that the number one reason why people choose not to be involved in an environmental assessment (EA) was that the "ultimate decisions were foregone." This was followed by "not knowing about the EA," "interests being represented by others" and "consultation fatigue." While respondents did mention being "too busy," this was well down the list of reasons. Clearly, there will be some people who will decide not to participate or will want to just be kept informed or will want to influence the decision in more passive ways. Tools like a public registry, open houses and questionnaires will be useful in helping these people participate and may in fact encourage them to participate more actively.

Such efforts may, however, just result in tinkering and perhaps what is required is a complete rethinking of how to meaningfully involve citizens of large urban areas in widearea or any other type of forest planning. Clearly, there are essential elements to any participation process such as sound notice, access to information, and the provision of resources that would apply to programs for large urban areas (Shindler and Neburka 1997, Tuler and Webler 1999, Sinclair and Doelle 2003). There are also practitioners from communities like Toronto, Ottawa, Winnipeg and other large urban centres that have experience in trying to tap into the views of their citizens. Advisory committees have been a tool that has been successfully used in large urban areas (Sinclair 2002) and polls are again becoming more common. Citizen juries are also being tested in some jurisdictions. The current citizenjury process being carried out in British Columbia with regard to electoral reform will provide important insights regarding the utility of this tool. ${ }^{4}$ In the end, it is important to recognize that for large-area forest planning, different public involvement tools are required to meet the participation needs of an urban public versus those of local communities or those of interested stakeholders (Chambers and Beckley 2003).

\section{Conclusion}

As discussed above, numerous authors and government agencies have noted or support a movement from representative to a more participatory form of democracy within forest land-use planning and management. It is clear that such actions are also consistent with new models of forest management such as sustainable forest management (SFM). The significant outstanding issue then, is how participatory can we hope to make the representative system of democracy in Canada, a system that has its own inherent strengths. This is a very difficult issue to resolve and will, of course, vary by issue. The approach used here was to consider the opportunities provided for the public to influence decisions, not whether the governing agency somehow shared or relinquished power. As such, we were not questioning whether government representatives should be making decisions about resource management, but rather how they might include the public in making those decisions. So, how much participation is enough in this case relates to the way people have been involved and how their views have influenced decisions.

It is our view, then, that for decisions to be more participatory it is necessary that there be meaningful and effective public participation in large-area land-use planning processes. It is evident that Canadian provincial governments have begun to provide avenues for public participation in their respective forest land-use planning processes, particularly through the use of round tables of which citizens are members. However, these efforts have been directed mostly at those interests who are actively engaged in forest land-use planning issues. It is also clear that little well-directed effort

\footnotetext{
${ }^{4}$ See Citizens Assembly on Electoral Reform at http://www.citizensassembly.bc.ca/public.
} 
has been made to facilitate or promote the involvement of the Canadian "general" public, most of whom reside in large urban centres located outside Canada's boreal forest, which we feel is unreasonable and does not meet what might be considered a minimum effort at achieving a participatory process.

This failure is unfortunate because, for a number of reasons, large-area planning processes provide a good vehicle to involve urbanites in forest planning. For example, the areas being considered are large enough that those with an interest, if meaningfully informed of the process, will likely sit up and take notice. The planning is normative and thereby provides an opportunity for people to be involved early in the planning before operational field decisions are made. As well, these processes are amenable to those who have different levels of interest-from citizens who wish simply to discuss values regarding the use of Canadian forests to those who are better versed in the mechanisms and minutiae of day-to-day forest management. Information, resources and literature need to be produced for the purposes of creating the final land-use plan. Making this information available and of value to the general public may require repackaging, but the groundwork for this will already have been done. Finally, there are many community groups in urban centres that could be used as links to the broader public.

Although there are challenges, the views and opinions of the urban population should be tapped because they represent the majority of the owners of public land. Many have perspectives that are different and refreshing from those directly affected, and many have views about how our natural resources should be used and want meaningful opportunities to voice them. As such, it is time that large-area land-use planning processes recognize the deficiencies in the processes undertaken to date and acknowledge that open houses and the opportunity to comment on draft plans are not enough to engage Canada's urban public.

\section{Acknowledgements}

The authors would like to acknowledge the financial support of the Sustainable Forest Management Network and thank the anonymous reviewers for their comments on the paper.

\section{References}

Blouin, G. 1998. Public involvement processes in forest management in Canada. For. Chron. 74(2): 224-226.

Bryant, D., D. Nielsen and L. Tangley. 1997. The last frontier forests: ecosystems and economics on the edge. World Resources Institute, Washington, DC. 42 p.

Buchy, M. and S. Hoverman. 2000. Understanding public participation in forest planning: a review. Forest Policy and Economics 1: 15-25.

Canadian Council of Forest Ministers (CCFM). 1992. Canada Forest Accord: Our Forests. Canadian Forest Service, Ottawa. [online]. Available from http://nfsc.forest.ca/accords/accord1.html. Canadian Council of Forest Ministers (CCFM). 1999. Criteria and Indicators of Sustainable Forest Management in Canada. Natural Resources Canada, Ottawa. 116 p.

Canadian Forest Service (CFS). 1997. The State of Canada's Forests 1996-1997. Natural Resources Canada, Ottawa. 129 p.

Canadian Standards Association (CSA). 2002. Sustainable forest management: requirements and guidance, Z809-02. Canadian Standards Association, Toronto, ON.
Castrilli, J.F. 2002. The Ontario forest, land use, and mining initiatives of 1999 and the management of public land in Canada in the $21^{\text {st }}$ Century: one step forward, two steps back. Canadian Env. Law Rep. (N.S.) 43: 11-105.

Chambers, F.H. and T. Beckley. 2003. Public involvement in sustainable boreal forest management. In P.J. Burton, C. Messier, D. W. Smith and W.L. Adamowicz (eds.). Towards sustainable management of the boreal forest. NRC Research Press, Ottawa. 1039 p.

Connor, D.M. 2001. Constructive citizen participation: a resource book. $8^{\text {th }}$ edition. Connor Development Services Ltd, Victoria, B.C. $250+$ p.

Creighton, J.L. 1995. Trends in the field of public participation in the United States. Interact: The Journal of Public Participation. 1(1): 7-23.

Diduck, A. and A.J. Sinclair. 1997. Testing the concept of critical environmental assessment (EA) education. In A.J. Sinclair (ed.). Canadian environmental assessment in transition. pp. 77-123. University of Waterloo, Waterloo, ON. 407 p.

Diduck, A. and A.J. Sinclair. 2002. Public involvement in environmental assessment: the case of the nonparticipant. Environmental Management 29(4): 578-588.

Drushka, K. 2003. Canada's forests: a history. McGill-Queen's University Press, Montreal and Kingston. 97 p.

Duinker, P. 1998. Public participation's promising progress: advances in forest decision-making. Commonwealth Forestry Review 77(2): 107-112.

East Side Planning Initiative (ESPI). Undated. Commitment to a comprehensive public participation process. ESPI, Winnipeg, MB. 6 p. East Side Planning Initiative (ESPI). 2004. "Promises to Keep ..." Towards a broad area for the East Side of Lake Winnipeg. ESPI, Winnipeg, MB. [online] Available from http://www.gov.mb.ca/conservation/wno/status-report/index.html\#status.

Environmental Commissioner of Ontario (ECO). 1997. Annual Report 1997: Open doors - Ontario's Environmental Bill of Rights. Environmental Commissioner of Ontario, Toronto, ON. 96 p.

Environmental Commissioner of Ontario (ECO). 1998. Annual Report 1998: Open doors - Ontario's Environmental Bill of Rights. Environmental Commissioner of Ontario, Toronto, ON. 289 p.

Environmental Commissioner of Ontario (ECO) 1999/2000. Annual Report 1999/2000: Changing perspectives. Environmental Commissioner of Ontario, Toronto, ON. 160 p.

Global Forest Watch Canada. 2000. Canada's forests at a crossroads: an assessment in the year 2000. World Resources Institute, Washington, DC. 114 p.

Government of Manitoba. Undated. East Side of Lake Winnipeg: Round Table terms-of-reference. Government of Manitoba, Winnipeg. 2 p. (pamphlet).

Government of Manitoba. 2000. Wide area planning to begin for east side of Lake Winnipeg. Government of Manitoba, Winnipeg. 9 August 2000: News release.

Government of Manitoba. 2001. East side Lake Winnipeg draft planning report released. Government of Manitoba, Winnipeg. 9 November 2001: News release.

Government of Manitoba. 2002. East Side Lake Winnipeg Broad Area Planning Initiative: Phase 1, Preliminary discussions, Final Report. Government of Manitoba, Winnipeg, MB. 204 p. Available from http://www.gov.mb.ca/conservation/wno/phase1/index.html Government of Manitoba. 2004. East Side Lake Winnipeg Broad Area Planning Initiative: Phase 2 Status Report. Government of Manitoba, Winnipeg, MB. [online] Available from http://www.gov. $\mathrm{mb} . c a /$ conservation/wno/status-report/index.html\#status

Government of Manitoba, Department of Conservation. 2002. Next steps: priorities for sustaining Manitoba's forests. Manitoba Conservation, Winnipeg. 8 p.

Government of Ontario. 1998. Consolidated recommendations of the Boreal West, Boreal East and Great Lakes-St. Lawrence Round Tables. Government of Ontario. 84 p. 
Government of Ontario. 2001. The evolution of Ontario's Living Legacy. Queens Printer, Toronto, ON. 82 p.

Grant, W.P. 1990. Forestry and forest products. In W.D. Coleman and G. Skogstad (eds.). Policy communities and public policy in Canada: a structural approach. pp. 118-140. Copp Clark Pitman Ltd., Toronto, ON. 338 p.

Higgelke, P.E. and P.N. Duinker. 1993. Open doors: public participation in forest management in Canada. Lakehead University, Thunder Bay, ON. 36 p.

Howlett, M. and J. Rayner. 1995. Do ideas matter? Policy network configurations and resistance to policy change in the Canadian forest sector. Can. Public Admin. 38(3): 382-410.

Howlett, M. and J. Rayner. 1997. Opening up the woods?: the origins and future of contemporary Canadian forest policy conflicts. National History 1(1): 35-48.

McGurk, B., A.J. Sinclair and A.P. Diduck. 2006. An assessment of stakeholder advisory committees in forest management: case studies from Manitoba, Canada. Society and Natural Resources 19(9): 809-826.

National Forest Strategy Coalition (NFSC). 2003. National forest strategy 2003-2008. Sustainable forests: a Canadian commitment. NFSC, Ottawa. 26 p.

National Round Table on the Environment and the Economy. 2003. NRTEE conservation of natural heritage case studies: \#3 Lands for Life (Ontario). NRTEE, Ottawa. [online]. Available from http://www.nrtee-trnee.ca/eng/programs/Current_Programs/ Nature/Natural-Heritage/Documents/Lands-for-Life-CaseStudy_E.pdf

Parkins, J. 2002. Forest management advisory groups in Alberta: an empirical critique of an emergent public sphere. Canadian Journal of Sociology 27(2): 163-184.

Parliament of Canada - Report of the senate sub-committee on boreal forest of the standing senate committee on agriculture and forestry. 1999. Competing realities: the boreal forest at risk. Parliament of Canada, Ottawa. [online]. Available from http://www. parl.gc.ca/36/1/parlbus/commbus/senate/com-e/bore-e/rep-e/ rep09jun99-e.htm

Peterson, T. 1972. Chapter 3. Manitoba: ethnic and class politics in Manitoba. In M. Robb (ed.). Canadian provincial politics: the party systems of the ten provinces. pp. 69 - 115. Prentice-Hall, Scarborough, ON. 318 p.

Petts, J. 1999. Chapter 8. Public participation and environmental impact assessment. In J. Petts (ed.) Handbook of environmental impact assessment. pp. 145-177. Blackwell Science, Oxford, UK. 960 p. Praxis. 1988. Manual on Public Involvement: Planning and Implementing Public Involvement Programs. Federal Environ-mental Assessment Review Organization (FEARO), Ottawa, ON.

Roberts, R. 1995. Public involvement: from consultation to participation. In F. Vanclay and D.A. Bronstein (eds.). Environmental and social impact assessment. pp. 221-246. John Wiley and Sons, Chichester. $325 \mathrm{p}$.

Robinson, D., M. Robson and R. Rollins. 2001. Towards increased citizen influence in Canadian forest management. Environments 29(2): 21-41.
Ross, M.M. 1995. Forest management in Canada. The University of Calgary, Calgary, AB. 52 p.

Sanderson, E.W., M. Jaiteh, M.A. Levy, K.H. Redford, A.V. Wannebo and G. Woolmer. 2002. The human footprint and the last of the wild. BioScience 52(10): 891-904.

Shindler, B.A., T.M. Beckley and C. Finley. 2003. Seeking sustainable forests in North America. In B.A. Shindler, T.M. Beckley and C. Finley (eds.). Two paths toward sustainable forests: public values in Canada and the United States. pp. 4-17. Oregon State University Press, Corvallis, OR. 359 p.

Shindler, B.A. and J. Neburka. 1997. Public participation in forest planning: 8 attributes of success. Journal of Forestry 95(1):17-19.

Sinclair, A.J. 2002. Public consultation for sustainable development policy initiatives: Manitoba approaches. Public Studies Journal 30(4): 423-443.

Sinclair, A.J. and M. Doelle. 2003. Using law as a tool to ensure meaningful public participation in environmental assessment. J. Environ. Law Pract. 12: 27-53.

Statistics Canada. 2004a. Population, provinces and territories. [online]. Available from http://www40.statcan.ca/101/cst01/demo02.htm.

Statistics Canada. 2004b. Population of census metropolitan areas, 2001 census boundaries. [online]. Available from http://www40.statcan.ca/101/cst01/demo05a.htm.

Statistics Canada. 2004c. Census geography-highlights and analysis. [online]. Available from http://geodepot.statcan.ca/Diss/Highlights/ Highlights_e.cfm.

Steadman, R.C. and J. Parkins. 2003. Public involvement in forest management: toward a research program in Alberta. In B.A. Shindler, T.M. Beckley and C. Finley (eds.). Two paths toward sustainable forests: public values in Canada and the United States. pp. 131-148. Oregon State University Press, Corvallis, OR. 359 p.

Sterne, P. and S. Zagon. 1997. Public consultation guide: changing the relationship between government and Canadians. Canadian Centre for Management Development, Ottawa, ON. 96 p.

Toronto Star. 1998a. Ban spring bear hunt. 15 April 1998. p. A7

Toronto Star. 1998b. Group's anti-hunting ads aimed at toppling Tories. 26 November 1998. p. B6.

Toronto Star. 1999a. Bearing down on the Harris Tories. 2 February 1999. p. A19.

Toronto Star. 1999b. The bear hunt's bête noire. 6 February 1999. p. B1. Tuler, S. and T. Webler. (1999). Voices from the forest: what participants expect of a public participation process. Society and Natural Resources 12: 437-453.

United Nations Environment Programme (UNEP). 2001. An assessment of the status of the world's remaining closed forests. UNEP/DEWA/TR 01-2. $50 \mathrm{p}$.

Wellstead, A.M., R.C. Stedman and J.R. Parkins. 2003. Understanding the concept of representation within the context of local forest management decision making. Forest Policy and Economics 5(1): 1-11.

Winnipeg Free Press (WFP). 2003. Tories keep their rural foothold: NDP easily holds on to North ridings. 4 June 2003. p. B2. 